\title{
MULTIPLE ANAMOLIES OF THYROID GLAND: A CASE REPORT
}

\author{
Krishnamurthy V. R ${ }^{1}$, Halesha B. R ${ }^{2}$, Manjunath C. S 3 , Ishwara Prasad G. D ${ }^{4}$
}

\section{HOW TO CITE THIS ARTICLE:}

Krishnamurthy V. R, Halesha B. R, Manjunath C. S, Ishwara Prasad G. D. "Multiple Anamolies of Thyroid Gland: A Case Report". Journal of Evolution of Medical and Dental Sciences 2014; Vol. 3, Issue 68, December 08;

Page: 14694-14697, DOI: $10.14260 /$ jemds/2014/3972

\begin{abstract}
BACKGROUND: Thyroid gland is the first endocrine gland to develop within 24 days, as median endodermal thickening in the floor of primordial pharynx.. ${ }^{1}$ The gland has two lobes shaped roughly like a slender pears, hugging the anterolateral aspect of the cervical trachea from the level of the thyroid cartilage to $5^{\text {th }}$ and $6^{\text {th }}$ tracheal ring. ${ }^{2}$ The anatomy of the vital endocrine gland is relevant both to non-operating clinician and for operating surgeons. AIMS AND OBJECTIVES: To study the anamolies of the thyroid gland. MATERIALS AND METHODS: During routine dissection in department of Anatomy, Hassan Institute of Medical Sciences, Hassan, Karnataka. RESULTS: Multilobed thyroid gland with absence of isthmus associated with levator glandulae thyroideae was noted. CONCLUSION: Surgeons planning for Thyroidectomy should have knowledge of thyroid anatomy and its anatomical variation for better planning of safe and effective surgery.
\end{abstract}

KEYWORDS: Agenesis, Thyroid gland, Thyroglossal duct, Thyroidectomy.

INTRODUCTION: The thyroid gland is situated low down at the front of the neck, it consist of two symmetrical lobe united by an isthmus that lies in front of 2, 3 and $4^{\text {th }}$ tracheal ring. The isthmus joins the anterior surface of the lobes towards their lower poles. The posterior surface of the isthmus is firmly adherent to 2, 3 and $4^{\text {th }}$ tracheal ring and pretracheal fascia is here fixed between them. This fixation and investment of the whole gland by pretracheal fascia is responsible for the gland moving up and down with larynx during swallowing. ${ }^{3}$

As the embryo and tongue grows, the developing thyroid gland descends in the neck ventral to hyoid and laryngeal cartilage by thyroglossal duct. By $7^{\text {th }}$ week thyroid gland assume definitive shape and usually located in final site of the neck. Thyroglossal duct normally degenerate and disappears ${ }^{1}$. It may be attached to inferior border of the hyoid bone by fibrous or smooth muscle fibers as levator glandulae thyroideae.

A smaller portion of the thyroid substance often projects upwards from the isthmus, generally to the left of the midline as a pyramidal lobe, represents a development of glandular tissue from caudal end of the thyroglossal duct. ${ }^{3}$

MATERIALS AND METHODS: Dissection instruments for dissection and 10\% formalin solution used as preservative for specimen. During routine dissection in department of Anatomy, Hassan Institute of Medical Sciences in year 2009 and 2010. In the dissection of neck region, a multilobed thyroid gland with other anomalies was found and photograph of the specimen was taken after dissection.

OBSERVATION: During the routine dissection in department of anatomy, we found the multilobed thyroid gland with absence of isthmus and presence of levator glandulae thyroideae from the lateral lobe attached superiorly to the hyoid bone (Images 1 and 2). 


\section{CASE REPORT}

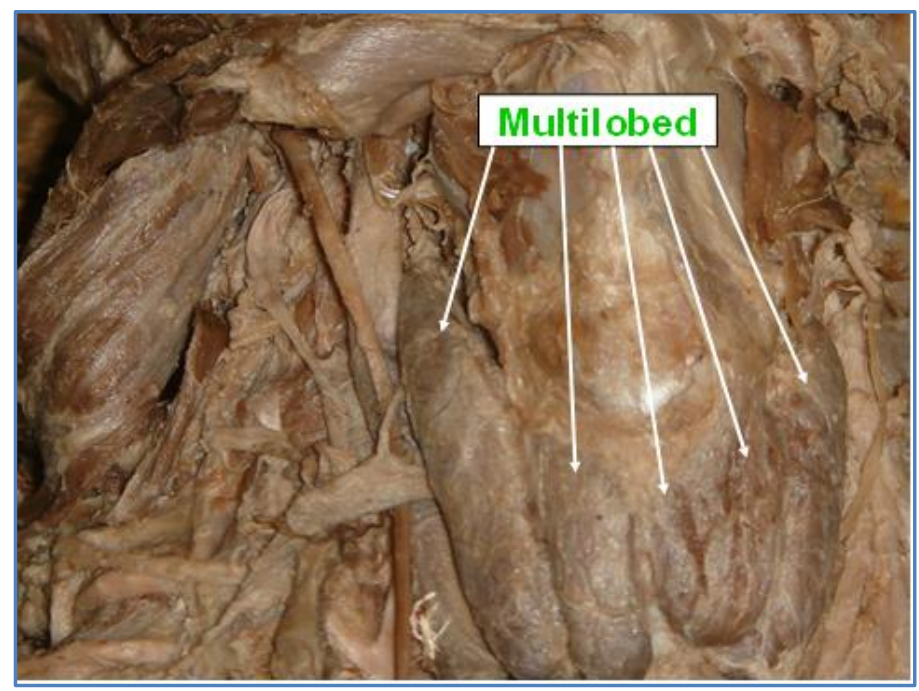

\section{Image 1: Specimen showing multilobed thyroid gland}

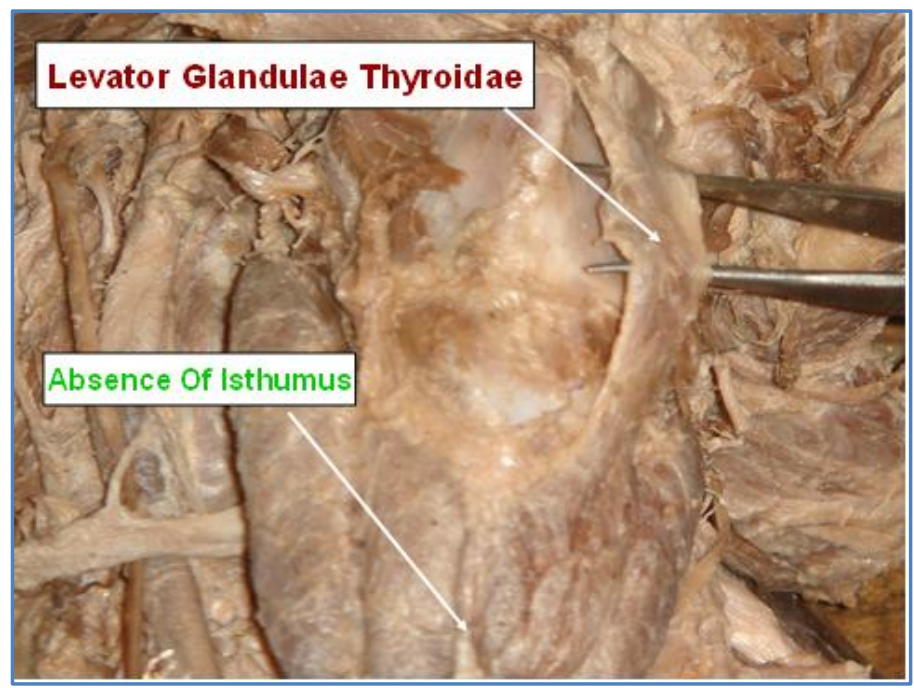

Image 2: Specimen showing Levator glandulae thyroidae

DISCUSSION: The thyroid gland develops from the proliferation of cells from the caudal end of thyroglossal duct. The median thickening of diverticulum from endodermal floor of $1^{\text {st }}$ and $2^{\text {nd }}$ pouch, which at the later stage of $4^{\text {th }}$ week form thyroglossal duct. The thyroglossal duct grows caudally and bifurcates into two lobes and isthmus. The high division of thyroglossal duct results in absence of isthmus and two independent lobes.

Agenesis of isthmus was reported in various studies, conducted by Marshall CF (10\%), ${ }^{4}$ Joshi SP (16.66\%), ${ }^{5}$ Rande (33\%), ${ }^{6}$ Pastrol (5-10\%), ${ }^{7}$ Dixit (14.6\%) ${ }^{8}$ and wounchvng (3\%).

After the appearance of thyroid gland by 7 th week, the thyroglossal duct normally degenerate and disappears. But in few cases it may remain as fibrous or smooth muscle tissue called Levator 


\section{CASE REPORT}

glandulae thyroideae connecting the isthmus and hyoid bone. Presence of levator glandulae thyroideae was observed by Joshi SD ${ }^{5}$ (30\%), Sultan $(47 \%)^{9}$ and Rande (49.5\%). ${ }^{6}$

The pyramidal lobe is differentiates from, distal end of the thyroglossal duct extends superiorly from isthmus.

In a study conducted by Marshall CF, presence of pyramidal lobe was reported in 26 cases (43\%). Among them, pyramidal lobe was attached to hyoid bone in 17 cases and fascia covering thyroid cartilage in 9 cases. Similar findings were observed in other studies reported by Joshi SD $(37.7 \%)^{5}$ and Sultan $(26.66 \%) .{ }^{9}$

According to Sultana ${ }^{9}$ et al, the presence of levator glandulae thyroideae and pyramidal lobe was observed in $73.33 \%$ of Bangladeshi people. A case of absent right lobe of thyroid was reported by Marshall $\mathrm{CF}^{4}$ et al.

CONCLUSION: Anomalies of thyroid gland are common. Agenesis of isthmus of thyroid gland was seen in 10-30\% persons and incidence of pyramidal lobe associated with levator glandulae thyroideae is 7.31\%, but more in Bangladeshi people (73.33\%).

Surgeons planning for thyroidectomy, should have a knowledge of thyroid anatomy and its anatomical variation for better planning of safe and effective surgery.

\section{REFERENCES:}

1. Keith and Moore: The developing Human clinically oriented embryology. $8^{\text {th }}$ edition: $173-175$.

2. Lee Mc Gregors Synopsis of surgical Anatomy. 12th edition: 1996:198- 205.

3. Chummy S, Sinnatamby. Last's Anatomy: Regional and Applied.11 th edition: Churchill Livingstone; 2006: 351-353.

4. Marshall CF. Variation in the form of thyroid gland in man. J Anat 1895; 29: 234-39.

5. Joshi SD, Joshi SS, Daimi SR, Athavale SA. The thyroid gland and its variations: a cadaveric study. Folia Morphol 2010; 69:47-50.

6. Ranade AV, Rain R, Pai MM et al, Anatomical variation of thyroid gland: Surgical implications. Singapore Med J 2008; 49(10): 831-34.

7. Pastor VJF, Gil VJA, De Paz Fernández FJ, Cachorro MB: Agenesis of the thyroid isthmus. Eur J Anat 2006; 10:83-84.

8. 8. Dixit D, Shilpa MB, Harsh MP, Ravishankar MV. Agenesis of isthmus of thyroid gland in adult human cadavers: a case series Cases J. 2009; 2: 6640.

9. Sultana S, Mannan S, Ahmed M, Rahman M, Khan M, Khalil M. An anatomical study on pyramidal lobe of thyroid gland in Bangladeshi people. Mymensingh Med J 2008 Jan; 17(1):8-13. 


\section{AUTHORS:}

1. Krishnamurthy V. R.

2. Halesha B. R.

3. Manjunath C. S.

4. Ishwara Prasad G. D.

\section{PARTICULARS OF CONTRIBUTORS:}

1. Assistant Professor, Department of General Surgery, Hassan Institute of Medical Sciences, Hassan.

2. Assistant Professor, Department of General Medicine, Hassan Institute of Medical Sciences, Hassan.

3. Assistant Professor, Department of Anatomy, Hassan Institute of Medical Sciences, Hassan.
4. Assistant Professor, Department of General Surgery, Hassan Institute of Medical Sciences, Hassan.

\section{NAME ADDRESS EMAIL ID OF THE CORRESPONDING AUTHOR:}

Dr. Halesha B. R,

Assistant Professor,

Department of General Medicine,

Hassan Institute of Medical Sciences,

Hassan.

Email: haleshrashmi@gmail.com

Date of Submission: 02/12/2014.

Date of Peer Review: 03/12/2014.

Date of Acceptance: 04/12/2014.

Date of Publishing: 08/12/2014. 